\title{
IMPLEMENTASI KEBIJAKAN PENGEMBANGAN DAN PEMBERDAYAAN KOMUNIKASI SOSIAL DI DINAS KOMUNIKASI, INFORMATIKA DAN STATISTIK KOTA CIREBON
}

\section{IMPLEMENTATION OF THE POLICY OF DEVELOPING AND EMPOWERING SOCIAL COMMUNICATION IN LOCAL OFFICE OF COMMUNICATION, INFORMATICS AND STATISTICS, CIREBON CITY}

\author{
Nurudin Siraj ${ }^{1 *}$, Agus Supriyadi², Nur Aulia Maulidina ${ }^{3}$ \\ 1,2Program Studi Ilmu Administrasi Negara, Fakultas Ilmu Sosial dan Ilmu Politik, Universitas \\ Swadaya Gunung Jati Cirebon \\ 3Program Studi Ilmu Administrasi Negara, Fakultas Ilmu Sosial dan Ilmu Politik, Universitas \\ Swadaya Gunung Jati Cirebon \\ *Korespondensi: Nurudin Siraj. Email: imammahdi264@gmail.com
}

(Diterima: 12 Maret 2019; Ditelaah: 27 Maret 2019; Disetujui: 2 April 2019)

\begin{abstract}
The research focuses on describing the implementation of the policy of developing and empowering social communication institutions of community information groups in Kejaksan Subdistrict, Cirebon City. In relation to the policy implementation, questions of the research are: (1) how the policy of community information groups in Kejaksan Subdistrict is implemented, (2) what factors support and inhibit the policy implementation in Kejaksan Subdistrict, and (3) what efforts are conducted to develop and to empower the social communication institutions of community information groups in Kejaksan Subdistrict. Method of the research is descriptive-qualitative. Data of the research are collected through observation and interviews. Results of the research indicate that the community information groups can be the facilitator for the community, the partner of the local government, the aspiration and information channel for the community. The implementation of the government policy of developing and empowering social communication institutions of community information groups in Kejaksan Subdistrict finds another dimension, namely the importance of budget and fund and monitoring, in addition to the factors of policy implementation used as an approach of the research.
\end{abstract}

Keywords: Policy Implementation, Community Information Group, Social Communication, Empowerment.

\begin{abstract}
ABSTRAK
Fokus penelitian ini adalah implementasi kebijakan pengembangan dan pemberdayaan lembaga komunikasi sosial kelompok informasi masyarakat di Kelurahan Kejaksan Kota Cirebon. Terkait implementasi kebijakan tersebut, masalah penelitian diidentifikasi sebagai berikut: (1) Bagaimana implementasi kebijakan kelompok informasi masyarakat di Kelurahan Kejaksan, (2) Faktor-faktor apa yang menjadi pendukung dan penghambat implementasi kebijakan pemerintah dalam pengembangan dan pemberdayaan lembaga komunikasi sosial kelompok informasi masyarakat di Kelurahan Kejaksan Kota Cirebon, (3) Upaya-upaya apa yang perlu dilaksanakan dalam pengembangan dan pemberdayaan lembaga komunikasi sosial kelompok informasi masyarakat di Kelurahan Kejaksan Kota Cirebon. Metode penelitian bersifat deskriptif-kualitatif. Pengumpulan data dilakukan melalui observasi dan wawancara. Hasil penelitian menunjukkan bahwa kelompok informasi masyarakat dapat menjadi fasilitator bagi masyarakat, mitra dari pemerintah daerah, penyalur aspirasi dan arus informasi bagi masyarakat. Pelaksanaan kebijakan pemerintah mengenai pengembangan dan pemberdayaan lembaga komunikasi sosial kelompok informasi masyarakat di Kelurahan Kejaksan menemukan dimensi lain, yaitu pentingnya anggaran dana dan monitoring, selain faktor-faktor implementasi kebijakan yang dijadikan sebagai pendekatan di dalam penelitian ini.
\end{abstract}

Kata Kunci: Implementasi Kebijakan, Kelompok Informasi Masyarakat, Komunikasi Sosial, Pemberdayaan.

Nurudin Siraj. 2019. Implementasi Kebijakan Pengembangan dan Pemberdayaan Komunikasi Sosial di Dinas Komunikasi, Informatika dan Statistik Kota Cirebon. 


\section{PENDAHULUAN}

Informasi saat ini merupakan kebutuhan utama bagi setiap orang, di samping kebutuhan akan sandang, pangan serta papan. Informasi terjadi atas dasar komunikasi antar individu satu dan individu yang lainnya. Pada tahap perkembangan selanjutnya hadirlah Kelompok Informasi Masyarakat (KIM) yang terdiri dari berbagai komunitas yang bergerak di bidang pemanfaatan, pengolahan dan penerapan informasi melalui media massa cetak dan elektronik, serta media lainnya. KIM merupakan lembaga layanan publik yang dibentuk dari, oleh, dan untuk masyarakat yang berorientasi pada layanan informasi dan pemberdayaan masyarakat sesuai dengan Undang-Undang Nomor 14 Tahun 2008 Tentang Keterbukaan Informasi Publik dan Peraturan Menteri Komunikasi dan Informatika Nomor 08/Per/M. KOMINFO/06/2010 Tentang Pedoman Pengembangan dan Pemberdayaan Lembaga Komunikasi Sosial.

Tujuan KIM antara lain untuk memenuhi kebutuhan informasi yang memberikan manfaat bagi masyarakat, meningkatkan kesejahteraan dan kecerdasan, meningkatkan kemakmuran, kesejahteraan dan keadilan masyarakat dan meningkatkan kualitas SDM dalam mendukung keberhasilan pembangunan. Keberadaan KIM diharapkan mampu menjadi jembatan penyampaian informasi mulai dari pusat kota sampai ke pelosok perdesaan (Pada et al., 2015). Seiring dengan arus informasi yang semakin tinggi, maka keberadaan KIM merupakan upaya pemberdayaan masyarakat dengan mengembangkan paradigma komunikasi dengan masyarakat (communication with the people) bukan lagi komunikasi untuk masyarakat (communication for the people) (Pada et al., 2015).

Percepatan Inovasi Kelompok Informasi Masyarakat Guna Mewujudkan Masyarakat Berbasis Informasi di Kelurahan Kejaksan Kota Cirebon dengan cara penerapan inovasi teknologi dengan membentuk KIM. Sejalan dengan semakin meningkatnya dinamika pembangunan dan derasnya tuntutan perubahan masyarakat kearah kehidupan yang lebih baik, dunia informasi menjadi salah satu bagian terpenting dalam mewujudkan perubahan. Khususnya informasi yang dapat mendorong terbangunnya pemberdayaan masyarakat.

Infomasi yang seharusnya sampai kepada masyarakat menjadi terputus aliran informasinya karena sebagian masyarakat tidak mampu menjangkau informasi tersebut dikarenakan keterbatasan pengetahuan Teknologi Informasi dan Komunikasi. Sehingga membutuhkan suatu solusi untuk menyelesaikan masalah seperti ini. Untuk mengatasi kondisi demikian maka peningkatan pembangunan kepada masyarakat, merupakan salah satu upaya dalam pelayanan informasi masyarakat untuk mendapatkan informasi. Khususnya yang terkait dengan informasi penyelenggaraan pembangunan dan isu-isu strategis yang perlu diketahui oleh masyarakat serta upaya-upaya pemerintah dalam menyikapi setiap kejadian yang timbul di masyarakat.

Dengan menerapkan implementasi kebijakan pemerintah dalam melaksanakan Pengembangan Dan Pemberdayaan kepada masyarakat untuk menggunakan inovasi Kelompok Informasi Masyarakat Guna Mewujudkan Masyarakat Berbasis Informasi maka permasalahan kurangnya pengetahuan masyarakat dan semakin menurunnya tingkat pengetahuan, khususnya informasi dan komunikasi dapat diatasi.

Implementasi kebijkana ini juga dapat dilakukan pada Program Pembinaan Anak Jalanan di Kota Cirebon khususnya di Dinas Sosial, Tenaga Kerja dan Transmigrasi belum berhasil secara optimal hal ini dapat dilihat dari: (a) Aktivitas Implementasi Komunikasi antar Organisasi; (b) Karakteristik Agen Pelaksana; (c) Kondisi Sosial, Ekonomi dan Politik; (d) Kecenderungan Aparat Pelaksana (Rianto Prakoso Gumilang, 2013).

\section{MATERI DAN METODE}




\section{Konsep/Teori yang Relevan}

Kebijakan: Furlong (2005) seperti yang dikutip oleh Nugroho (2014: 105) berpendapat bahwa: "Kebijakan publik tidak dibuat dalam keadaan vakum. Kebijakan Publik dipengaruhi oleh kondisi sosial dan ekonomi, nilai politik yang berlaku dan suasana hati masyarakat pada suatu waktu, struktur pemerintahan, norma nasional serta norma budaya lokal, merupakan variabel yang lain."

Kebijakan Publik adalah suatu keputusan yang dimaksudkan untuk tujuan mengatasi permasalahan yang muncul dalam suatu kegiatan tertentu yang dilakukan oleh instansi pemerintah dalam rangka penyelenggaraan pemerintahan (Mustopadidjaja, 2002).

Dari definisi diatas dapat disimpulkan bahwa kebijakan dapat digunakan unutk mengambil suatu tindakan ataupun keputusan dari suatu pemikiran untuk mencapai suatu tujuan tertentu. Kebijakan yang berlaku juga dipengaruhi oleh lingkungan sekitar.

Implementasi Kebijakan: Implementasi kebijakan dipandang dalam pengertian yang luas, merupakan tahap dari proses kebijakan segera setelah penetapan undang-undang. Implementasi dipandang secara luas mempunyai makna pelaksanaan undang-undang di mana berbagai aktor, organisasi, prosedur, dan teknik bekerja bersama-sama untuk menjalankan kebijakan dalam upaya untuk meraih tujuan-tujuan kebijakan atau programprogram. Suatu program kebijakan harus diimplementasikan agar mempunyai dampak atau tujuan yang diinginkan. Implementasi dipandang secara luas mempunyai makna pelaksanaan undangundang di mana sebagai aktor, organisasi, prosedur dan teknik bekerja bersama-sama untuk menjalankan kebijakan dalam upaya untuk meraih tujuan-tujuan kebijakan atau program-program. Implementasi pada sisi lain merupakan fenomena yang kompleks yang mungkin dapat dipahami sebagai salah satu proses, suatu keluaran (output), maupun sebagai dampak (outcame).

Menurut Grindle (dalam Winarno 2016: 135), tugas implementasi adalah "membentuk suatu kaitan (linkage) yang memudahkan tujuan-tujuan kebijakan bisa direalisasikan sebagai dampak dari suatu kegiatan pemerintah. Oleh karena itu, tugas implementasi mencakup terbentuknya ( $a$ policy delivery system,) di mana saranasarana tertentu dirancang dan dijalankan dengan harapan sampai pada tujuan yang diinginkan."

Berdasarkan uraian tersebut dapat disimpulkan bahwa implementasi merupakan suatu proses yang dinamis, di mana pelaksana kebijakan melakukan suatu aktivitas atau kegiatan, sehingga pada akhirnya akan mendapatkan suatu hasil yang sesuai pencapaian tujuan akhir (output), yaitu tercapai atau tidaknya tujuan-tujuan yang ingin diraih.

Berkaitan dengan beberapa pemikiran tentang implementasi sebagaimana telah diuraikan di atas, peneliti menggunakan model implementasi yang dikemukakan oleh George Charles Edward III (dalam Winarno 2016: 155). Edward III menjelaskan bahwa implemen-tasi kebijakan adalah krusial bagi public administration dan public policy. Empat faktor tersebut menjadi kriteria penting dalam implementasi suatu kebijakan, yaitu: (1) Komunikasi. (2) Sumber Daya. (3) Disposisi. (4) Struktur Birokrasi.

Kelompok Informasi Masyarakat: Kelompok Informasi Masyarakat (KIM) merupakan revitalisasi dan reaktualisasi dari kolempencapir yang disesuaikan dengan paradigma pembangunan dan pemerintah dewasa ini, dengan mengedepankan prinsip demokrasi dan good governance. KIM berperan dalam memperlancar kontribusi dan distribusi informasi kepada masyarakat selain itu menjembatani antara masyarakat dan pemerintah dalam penyebaran informasi dan penyerapan aspirasi. Masyarakat membentuk kelompok untuk mengatasi 
persoalan bersama melalui akses dan pemberdayaan informasi.

Direktorat Kelembagaan Komunikasi Sosial (2008: 1) menjelaskan definisi KIM, yaitu: "Kelompok Informasi Masyarakat (KIM) adalah lembaga layanan publik yang dibentuk dan dikelola dari, oleh dan untuk masyarakat yang berorientasi pada layanan informasi dan pemberdayaan masyarakat sesuai dengan kebutuhannya."

Lembaga Komunikasi di sini adalah Kelompok Informasi Masyarakat atau kelompok sejenis lainnya, selanjutnya disingkat KIM, yang dibentuk oleh masyarakat, dari masyarakat dan untuk masyarakat secara mandiri dan kreatif yang aktifitasnya melakukan kegiatan pengelolaan informasi dan pemberdayaan masyarakat dalam rangka meningkatkan nilai tambah sesuai dengan kebutuhannya (Komunikasi \& Informatika, 2017).

Tabel 1. Operasionalisasi Konsep Penelitian

\begin{tabular}{|c|c|c|}
\hline $\begin{array}{l}\text { Konsep/ } \\
\text { Aspek Kajian }\end{array}$ & Dimensi & Parameter \\
\hline \multirow{7}{*}{$\begin{array}{l}\text { Implementasi } \\
\text { Kebijakan }\end{array}$} & Komunikasi & $\begin{array}{lr}\text { Sosialisasi } & \text { tentang } \\
\text { Kelompok } & \text { Informas } \\
\text { Masyarakat } & \end{array}$ \\
\hline & \multirow[t]{2}{*}{$\begin{array}{l}\text { Sumber } \\
\text { Daya }\end{array}$} & $\begin{array}{l}\text { Jumlah dan Kemampuan } \\
\text { sumber daya manusia } \\
\text { dalam } \\
\text { mengimplementasikan } \\
\text { kebijakan }\end{array}$ \\
\hline & & Dukungan APBD (Dana) \\
\hline & \multirow[b]{2}{*}{ Disposisi } & $\begin{array}{l}\text { Respons/tanggapan } \\
\text { pelaksana kebijakan }\end{array}$ \\
\hline & & $\begin{array}{lr}\text { Konsistensi } & \text { isi dar } \\
\text { kebijakan } & \text { tentang } \\
\text { Kelompok } & \text { Informas } \\
\text { Masyarakat } & \end{array}$ \\
\hline & \multirow{2}{*}{$\begin{array}{l}\text { Struktur } \\
\text { Birokrasi }\end{array}$} & $\begin{array}{l}\text { Adanya prosedur operasi } \\
\text { yang standar (Standar } \\
\text { Operating Procedures } \\
\text { atau SOP) }\end{array}$ \\
\hline & & $\begin{array}{l}\text { Koordinasi dan } \\
\text { monitoring kepada } \\
\text { pelaksana kebijakan }\end{array}$ \\
\hline
\end{tabular}

\section{Metode Penelitian}

Penelitian ini menggunakan penelitian deskriptif-kualitatif yang berusaha untuk memberikan gambaran atau penjelasan yang tepat mengenai permasalahan yang diteliti, menginterpretasikan dan menjelaskan data secara sistematis berdasarkan fakta-fakta yang tampak atau sebagaimana adanya (Sugiyono, 2010: 15).

Dalam penelitian kualitatif yang murni sebenarnya tidak dikenal istilah populasi. Oleh karena itu, dalam penelitian kualitatif peneliti tidak menentukan populasi tetapi menentukan informan. Informan yaitu orang memberikan informasi, keterangan atau data yang berkaitan dengan permasalahan yang diteliti. Dalam suatu penelitian kualitatif informan menjadi sumber data utama. Jumlah informan dalam suatu penelitian kualitatif tergantung dari kebutuhan dan kedalaman penelitian itu sendiri. Informan pada penelitian ini adalah Informan Kunci yaitu: Kepala Bidang Komunikasi Publik. Sementara Informan Pendukung yaitu: Kasi Pemerintahan, Ketentraman dan Ketertiban Kelurahan Kejaksan dan Ketua Kelompok Informasi Masyarakat Kelurahan Kejaksan.

\section{HASIL DAN PEMBAHASAN}

\section{Implementasi Kebijakan Pengembangan dan Pemberdayaan Komunikasi Sosial pada Kelompok Informasi Masyarakat Kelurahan Kejaksan Kota Cirebon}

Implementasi kebijakan menjadi salah satu proses dari suatu kebijakan setelah adanya peraturan. Saat ini Indonesia tengah dalam upaya mewujudkan masyarakat informasi. Masyarakat informasi tidak hanya melulu mengenai pengukuran melalui kuantitas melainkan juga dari kualitas. Salah satu program yang dibuat oleh pemerintah untuk mendukung terwujudnya masyarakat informasi di Indonesia adalah dibentuknya program KIM atau Kelompok Informasi Masyarakat. Seperti Kelompok Informasi Masyarakat yang ada di Kota Cirebon. Program ini merupakan sebuah program yang ditujukan untuk masyarakat untuk mampu mengoptimalisasi manfaat informasi di kehidupan mereka. Pengembangan dan pemberdayaan terhadap Kelompok Informasi Masyarakat terutama yang ada dalam memenuhi kebijakan tentang 
pengembangan dan pemberdayaan komunikasi sosial bukanlah suatu hal yang mudah, meskipun sudah ada Kelompok Informasi Masyarakat yang berada di Kota Cirebon yang sudah mengimplementasikan kebijakan tersebut, tetapi ada pula Kelompok Informasi Masyarakat yang belum melaksanakan kebijakan pengembangan dan pemberdayaan Kelompok Informasi Masyarakat.

Menurut pendapat dari KABID Pengelolaan Komunikasi Publik mengenai implementasi kebijakan pengembangan dan pemberdayaan kelompok informasi masyarakat di Kelurahan Kejaksan Sesuai dengan Peraturan Menteri Komunikasi dan Informatika Nomor : 08/Per/M.Kominfo/ 6/2010 tentang Pedoman Pengembangan Pemberdayaan Lembaga Komunikasi Sosial ,pembangunan tanpa diimbangi dengan pengembangan kemampuan yang memadai di masyarakat akan menimbulkan suatu permasalahan. Kemajuan suatu teknologi informasi dan komunikasi diperlukan suatu pembelajaran, pelatihan hingga pendampingan penggunaan.

Kemudian menurut pemaparan Ibu Dra. Endang Nurasih Irianti selaku Kasi Pemerintahan, Ketentraman dan Ketertiban Kelurahan Kejaksan dapat diartikan bahwa perbaikan kualitas sumber daya manusia untuk siap memanfaatkan kemajuan teknologi komunikasi dan informasi merupakan hal yang tentunya harus diperhatikan. Salah satunya ialah melalui pembentuan sebuah kelompok di masyarakat yang berfokus pada informasi. Sebuah kelompok informasi sangat diperlukan oleh masyarakat saat ini untuk mampu memanfaatkan dan juga mengolah informasi menjadi sebuah jawaban atas permasalahan mereka.

Faktor Pendukung dan Faktor Penghambat dalam Implementasi Kebijakan Pengembangan dan Pemberdayaan Komunikasi Sosial pada Kelompok Informasi Masyarakat Kelurahan Kejaksan Kota Cirebon
Berdasarkan hasil wawancara dari pelaksana kebijakan disimpulkan bahwa faktor penghambat proses implementasi kebijakan pengembangan dan pemberdayaan pada kelompok informasi masyarakat Kelurahan Kejaksan sehingga kebijakan tidak berjalan dengan optimal.

Pertama: Dana atau anggaran, sesuai dengan apa yag sudah dijelaskan Ibu Ahadyah Dwi Agustinah, S.Sos selaku KABID Pengelolaan Komunikasi Publik di Dinas Komunikasi, Informatika dan Statistik Kota Cirebon dalam pemaparannya di atas untuk implementasi kebijakan pengembangan dan pemberdayaan pada kelompok informasi masyarakat agar berjalan dengan baik, memerlukan dana atau anggran tersendiri. Sedangkan dana atau anggaran untuk implementasi kebijakan pengembangan dan pember-dayaan pada kelompok informasi masyarakat tidak disediakan oleh pemerintah. Sehingga memerlukan dana khusus yang berasal dari swadaya anggota kelompok.

Kedua: Kurangnya pemahaman dari pelaksana kebijakan dalam mengimplementasikan kebijakan tentang kelompok informasi masyarakat ini, sehingga masyarakat pun masih banyak yang belum mengetahui adanya kelompok informasi masyarakat ini.

\section{Upaya-upaya dalam Mengatasi Hambatan Implementasi Kebijakan Pengembangan dan Pemberdayaan Komunikasi Sosial pada Kelompok Informasi Masyarakat Kelurahan Kejaksan Kota Cirebon}

Berdasarkan hasil wawancara dari pelaksana kebijakan aapat disimpulkan bahwa upaya yang dilakukan untuk mengatasi hambatan implementasi kebijakan pengembangan dan pemberdayaan komunikasi sosial pada kelompok informasi masyarakat yaitu dilakukan evaluasi secara terus menerus agar kelompok informasi masyarakat itu sendiri dapat berjalan secara lebih optimal, mengenalkan juga kepada generasi muda 
tentang bagaimana memanfaatkan informasi dan untuk anggaran dana itu sudah menjadi bahan diskusi agar anggaran dana untuk tiap tiap kelompok informasi masyarakat dapat terrealisasikan.

\section{KESIMPULAN DAN REKOMENDASI}

\section{Kesimpulan}

Berdasarkan hasil penelitian peneliti menyimpulkan, bahwa implementasi kebijakan dari Kelompok Informasi Masyarakat di Kelurahan Kejaksan adalah sebagai berikut:

Pertama: Mengacu Peraturan Menteri Komunikasi dan Informatika Nomor 08/Per/M.KOMINFO/06/2010 tentang Pedoman Pengembangan dan Pemberdayaan Lembaga Komunikasi Sosial. Dengan adanya peraturan diatas pemerintah seharusnya lebih melaksanakan kebijakankebijakan dengan baik, dalam hal ini peneliti menyimpulkan bahwa Kelompok Informasi Masyarakat dapat menjadi fungsi dalam penyebarluasan informasi di masyarakat agar dapat terwujudnya masyarakat informasi dan meningkatkan kualitas dari masyarakatnya itu sendiri. Pembentukan Kelompok Informasi Masyarakat sendiri dimaksudkan untuk meningkatkan kualitas sumber daya dari masyarakat dalam penyerapan dan pemanfaatan informasi, dan agar dapat memanfaatkan untuk pendidikan dan ekonomi mereka agar tahu bagaimana cara memanfaatkannya untuk kemajuan kehidupan mereka sendiri.

Kedua: Dalam penelitian ditemukan sejumlah faktor pendukung dan penghambat. Faktor pendukung pada proses implementasi kebijakan merupakan faktor yang menjadi terlaksananya kebijakan. Pada proses implementasi kebijakan pengembangan dan pemberdayaan kelompok informasi masyarakat di Kelurahan Kejaksan Kota Cirebon memiliki faktor pendukung bagi pelaksana kebijakan atau implementor. Faktor pendukung di kelompok informasi masyarakat di Kelurahan Kejaksan Kota Cirebon Peraturan Menteri
Komunikasi dan Informatika Nomor: 08/Per/M.Kominfo/6/2010 tentang Pedoman Pengembangan Pemberdayaan Lembaga Komunikasi Sosial, kemudian untuk penyadaran kepada masyarakat akan arti pentingnya informasi. Sedangkan, faktor penghambat dalam implementasi kebijakan pengembangan dan pemberdayaan kelompok informasi masyarakat di Kelurahan Kejaksan Kota Cirebon, yaitu karena anggaran dana yang terbatas dan belum pahamnya pelaksana kebijakan tentang pengembangan dan pemberdayaan kelompok informasi masyarakat.

\section{Rekomendasi}

Berdasarkan hambatan-hambatan yang dihadapi oleh pelaksana kebijakan atau implementor maka terdapat upayaupaya yang dilakukan oleh pelaksana kebijakan dalam menghadapi beberapa hambatan yang terjadi dalam proses implementasi kebijakan pengembangan dan pemberdayaan kelompok informasi masyarakat di Kelurahan Kejaksan Kota Cirebon yaitu evaluasi dengan melakuan rapat koordinasi tentang sudah seberapajauh KIM itu berkembang lalu juga melakukan monitoring terhadap kegiatan kegiatan apa saja yang sudah dilakukan oleh KIM di Kelurahan Kejaksan dan Kelurahan Kelurahan lain. Kemudian untuk anggaran dana akan dibicarakan agar sumber anggaran dana tidak berasal dari swadaya kelompok

\section{DAFTAR PUSTAKA}

\section{Buku}

Komunikasi, J., \& Informatika, M. D. A. N. (2017). Peran KIM Daerah Tertinggal dalam Memanage Informasi untuk Meningkatkan Pengetahuan dan Keterampilan Masyarakat Sekitar. The Role of Rural Areas KIM in Managing Information to Develop Local People Knowledge and Creativity, 6(April), 29-40.

Mustopadidjaya AR. 2002. Manajemen 
Proses Kebijakan Publik, Formulasi, Implementasi dan Evaluasi Kinerja. Jakarta: LAN.

Nugroho, Riant. 2014. Kebijakan Publik di Negara-negara Berkembang. Jakarta: Pustaka Belajar.

Pada, S., Informasi, K., Kim, M., Kabupaten, D., Barat, J., \& Desentralisasi, O. 2015. Pemberdayaan Lembaga Komunikasi Sosial. Development Policy Implementation And Development Institute of Social Communication (Studies in Public Information Group/KIM) In Pangandaran Regency of West. Mulyono Yalia Kondisi geografis Indonesia yang tersebar.

Rianto, Prakoso Gumilang, dkk. 2013. Implementasi Kebijakan Program Pembinaan Anak Jalanan di Kota Cirebon (Studi Kasus di Dinas Sosial, Tenaga Kerja dan Transmigrasi Kota Cirebon).

Sugiyono. 2008. Metode Penelitian Administrasi. Bandung: Alfabeta

Winarno, Budi. 2014. Kebijakan Publik Teori, Proses, dan Studi Kasus. Yogyakarta: CAPS (Center of Academic Publishing Service).

\section{Peraturan Perundang-undangan}

Peraturan Menteri Komunikasi dan Informatika Nomor 08/Per/M. KOMINFO/06/2010 tentang Pedoman Pengembangan dan Peberdayaan Lembaga Komunikasi Sosial.

Undang-Undang Nomor 14 Tahun 2008 tentang Keterbukaan Informasi Publik. 